\title{
Factors affecting susceptibility of the coral Montastraea faveolata to black-band disease
}

\author{
Greta S. Aeby ${ }^{1,3, *}$, Deborah L. Santavy ${ }^{2}$ \\ ${ }^{1}$ Department of Biology, University of West Florida, 11000 University Parkway, Pensacola, Florida 32514-5751, USA \\ ${ }^{2}$ US Environment Protection Agency, National Health and Environmental Effects Laboratory, Gulf Ecology Division, \\ 1 Sabine Island Drive, Gulf Breeze, Florida 32561-5299, USA \\ ${ }^{3}$ Present address: Hawaii Institute of Marine Biology, PO Box 1346, Kaneohe, Hawaii 96744, USA
}

\begin{abstract}
Black-band disease affects many species of tropical reef-building corals, but it is unclear what factors contribute to the disease-susceptibility of individual corals or how the disease is transmitted between colonies. Studies have suggested that the ability of black-band disease to infect coral is enhanced by different stressors. We examined the effect of both water temperature and mechanical injury on the ability of this disease to infect the reef coral Montastraea faveolata, and investigated the possibility of an interaction between the 2 stressors. Under laboratory conditions, Phormidium corallyticum was able to successfully invade all injured fragments but no uninjured fragments of M. faveolata, irrespective of temperature regime. We also determined whether the local coral-feeding butterflyfish Chaetodon capistratus was involved in the inter-colony transfer of black-band disease. In aquaria, the presence of $C$. capistratus increased the rate at which the disease spread from infected to non-infected fragments of $M$. faveolata. Both corals that were protected from and those that were exposed to fish predation contracted the disease. Hence, either direct oral transmission of the pathogen from colony to colony and/or indirect fecal transmission could be occurring. Variables such as potential stressors and/or disease vectors on a reef could contribute to the patterns of blackband disease observed in the field.
\end{abstract}

KEY WORDS: Black-band disease $\cdot$ Susceptibility $\cdot$ Coral $\cdot$ Coral injury $\cdot$ Coral disease $\cdot$ Transmission Vectors · Butterflyfish

\section{INTRODUCTION}

Black-band disease affects certain species of reefbuilding corals in the Caribbean, Florida Keys and Indo-Pacific regions (Rützler et al. 1983, Antonius 1985, Edmunds 1991, Kuta \& Richardson 1996, 2002). The 'black-band' is composed of a complex microbial community dominated by the filamentous cyanobacterium Phormidium corallyticum (Rützler \& Santavy 1983). The disease progresses as a consolidated band across the surface of a coral colony, destroying tissue by anoxic exposure and leaving only the exposed coral skeleton (Rützler \& Santavy 1983, Edmunds 1991, Carlton \& Richardson 1995, Richardson et al. 1997). Black-band disease is one of the few coral diseases for which the etiology and mechanism of coral death are known. However, little is understood of what factors contribute to the susceptibility of individual corals to black-band disease or of how the disease is transmitted between colonies.

In order for black-band disease (or any infection) to occur, the pathogen must first overcome the defenses of its potential host. Corals have a suite of defense mechanisms, e.g. muco-ciliary response to rid themselves of sediment and other settling organisms (Santavy \& Peters 1997, Mascarelli \& Bunkley-Williams 1999), various chemical (Gunthorpe \& Cameron 1990, Koh 1997, Gochfeld 2004) and nematocyst (Mariscal 1974, Hidaka \& Miyazaki 1984, Hidaka et al. 1987, Bigger 1988, Gochfeld 2004) defenses, and phagocytic 
cells that can engulf and destroy microorganisms (see also reviews by Mullen et al. 2004, and Sutherland et al. 2004). Certain species of corals become infected with black-band disease. However, it is uncertain how this disease is established on the corals or what factors contribute to their susceptibility. The disease is more prevalent during the warm summer months (Antonius 1981, 1985, Rützler et al. 1983, Taylor 1983, Edmunds 1991, Kuta \& Richardson 1996, Bruckner et al. 1997) and in locations where poor environmental conditions persist. Increases in black-band disease were observed by Antonius (1989) in polluted waters near industrialized areas, and by Bruckner et al. (1997) in areas with high sedimentation and algal overgrowth. Injury has also been found to increase a coral's susceptibility to black-band disease (Rützler et al. 1983). These findings suggest that the ability of black-band disease to infect corals is enhanced by different stressors, e.g. increased water temperature, water quality or injury. However, this hypothesis has never been tested under controlled laboratory conditions.

The first objective of this study was to examine the affect of both water temperature and mechanical injury on the ability of black-band disease to infect the reef coral Montastraea faveolata. We considered that there might also be an interaction between these 2 stressors in the attachment and invasion of the blackband microbial consortium. Increased water temperature may only result in infection by the black-band microbial consortium if there are stressed or injured colonies on the reef. Conversely, injury may only result in infection if the temperature is high enough to enhance bacterial growth. Hence, we also explored the interactions between temperature and injury and how these affect a coral's susceptibility to black-band disease.

Establishment of disease in a host population would not only require the ability to invade a host but also a mechanism of transfer between hosts. Transmission of disease between susceptible hosts can occur by direct contact, dispersal through air or water, or by vectors (Ewald 1987, 1994). Transmission of black-band disease has been shown to occur through direct contact (Rützler et al. 1983), and possibly transference by prevailing currents (Bruckner et al. 1997). However, studies on the distribution of black-band-affected colonies on reefs have not produced consistent patterns supporting any specific dispersal mechanisms (Bruckner 2002). One mechanism that has not been considered is the transmission of black-band disease by vectors. The study of coral disease often only examines putative coral-pathogen relationships or environmental factors that might contribute to a compromised host. However, corals are impacted by a variety of reef organisms, especially reef fishes. We know that reef fishes can have positive and negative impacts on corals. Coral predators, such as butterflyfishes or parrotfishes, can negatively impact the growth and distribution of corals (Neudecker 1979, Cox 1986, Kosaki 1988, Miller \& Hay 1998). In contrast, herbivorous fishes benefit the corals by grazing the algae that could otherwise compete with the corals for space on the reef (Jones et al. 1991). Close interactions between corals and reef fishes suggest that fishes could play an important role in coraldisease processes.

Butterflyfishes are common reef fishes that associate closely with live corals and are likely candidates for affecting the dynamics of disease transmission. They are coral predators that maintain territories or home ranges within a small area of the reef. They swim from colony to colony feeding repeatedly on the corals within their territories (Reese 1975, 1991, Hourigan 1987, Tricas 1989a, Kosaki 1999). A diseased coral located in a butterflyfish's territory, could be a source of the disease agent(s), with the fish acting as vector, transferring it to other colonies. Butterflyfishes could transmit blackband disease between colonies by oral and/or fecal transmission: Fishes feeding on diseased tissue could orally transmit the primary disease agent when they subsequently feed on a non-diseased coral, and/or fecal transmission could occur after they feed on the disease agent, which then passes through the gut and is redeposited on other corals during defecation.

Transmission of pathogens by vectors is common in the terrestrial environment (Aeschlimann 1991, McCallum et al. 2004), and has recently been documented in the marine environment. Sussman et al. (2003) found that the marine fireworm Hermodice carunculata is a vector for the coral-bleaching pathogen Vibrio shiloi. The common butterflyfish in the Florida Keys, Chaetodon capistratus, is a coral predator, and has been observed feeding directly on the black-band consortium from diseased corals within its home range (H. Hudson pers. comm.). This fish species is a likely candidate for transmission of black-band disease between colonies in South Florida. The second objective of this study was thus to determine if this butterflyfish aids in the transmission of black-band disease.

\section{MATERIALS AND METHODS}

Injury/temperature interaction. A factorial experimental design was used that employed an injured coral fragment, an uninjured coral fragment, lowtemperature exposure to simulate winter conditions (23 to $25.5^{\circ} \mathrm{C}$ ), and high-temperature exposure to simulate summer conditions (27.5 to $29.5^{\circ} \mathrm{C}$ ). We collected 7 large fragments from different coral colonies of Montastraea faveolata on reefs in the Florida Keys. The 
corals were allowed to recover in flow-through seawater tables at Mote Marine Laboratory, Summerland Key, for 1 to $2 \mathrm{~d}$, and were then dry-shipped in coolers (Bronikowski 1982) to the Gulf Breeze Laboratory (Florida), where they arrived within $24 \mathrm{~h}$. Coral fragments were immediately placed in large 90 gal (340 l) aquaria. After several days acclimation, each fragment was cut into 4 similar-sized pieces to ensure that genetically identical fragments of coral from the same colony were used for each experimental run. The coral fragments were allowed to recover for several days after cutting before use in the experiments. Each coral fragment was maintained in a 21 beaker of artificial salt water with aeration. The beakers were placed in an incubator at experimental temperature. Black-band mats were obtained from diseased colonies on reefs in the Florida Keys. They were maintained in large beakers of artificial seawater with small pieces of corals used as a food source. A bubbler was placed in each beaker, and they were kept in an incubator at approximately $29^{\circ} \mathrm{C}$ with a $12 \mathrm{~h}$ light/dark cycle.

For the experiment, an injury was created by scraping off a small area $\left(\sim 1 \mathrm{~cm}^{2}\right)$ of tissue with sterile forceps. A similar-sized black-band mat was then placed on each coral fragment. The mat was placed on the injured tissue in the injured treatment group and was usually similar in size to the injured area. All inoculated coral fragments were observed daily for evidence of attachment and invasion or penetration of Phormidium corallyticum mat into the coral tissue. Coral defense mechanisms against $P$. corallyticum were also examined. These included both the ability of the coral to remove the mat of $P$. corallyticum from the coral surface and the visual disappearance of the black-band mat from the beaker. Experiments were run for 8 to $9 \mathrm{~d}$.

Butterflyfish transmission experiments. In laboratory studies, we assessed whether fish aid in transmitting black-band disease by measuring the transmission rate of black-band disease from a diseased coral to a healthy coral in aquaria with and without the coral predator Chaetodon capistratus. Butterflyfish C. capistratus were obtained from a professional fish collector in the Florida Keys and allowed to acclimate to captivity for at least $1 \mathrm{wk}$ before use in experiments. Since only limited amounts of coral were available their diet was supplemented daily with live brine shrimp. To minimize the number of fish removed from the reefs, each butterflyfish was used for 2 experimental runs.

We obtained and treated 8 large fragments of Montastraea faveolata as described above, with the exception that each coral fragment was cut into 6 pieces. Fragments from the same coral colony were used for 1 experimental run or replicate. Fresh black-band mats were periodically obtained from the field and used throughout the experiment.
In 70 gal (265 l) aquaria 2 healthy, uninfected, coral fragments and 1 fragment artificially infected with black-band disease were placed onto plastic-mesh trays. The diseased fragment was positioned equidistant between the 2 healthy fragments $(\sim 10 \mathrm{~cm}$ apart). We used 2 identical aquaria in a paired design to control for waterborne transmission of black-band disease between corals; 1 tank contained a butterflyfish and 1 did not. Strong bubblers were placed in the aquaria to provide good water circulation and similar water motion. Periodic, partial, water changes were conducted in each aquarium to maintain water quality. We investigated whether the mechanism of transfer of black-band disease from fish to healthy coral was oral and/or fecal: 1 of the 2 healthy coral fragments was protected from fish predation by a plastic-mesh predator-exclusion cage, and 1 was exposed to fish predation. All experimental aquaria were maintained at $28^{\circ} \mathrm{C}$ with a $12 \mathrm{~h}$ light/dark cycle. We found these conditions optimal for maintaining all 3 organisms (fish, coral, black-band consortium) in a healthy condition.

All corals were examined daily for signs of blackband disease and the presence of Phormidium corallyticum filaments. If evidence of tissue invasion was observed on the coral's surface, we verified the presence of live $P$. corallyticum filaments in the black-band microbial consortium by microscopic examination. The experiment was terminated when $P$. corallyticum filaments were observed invading the tissue surface of any of the healthy corals ( 44 healthy pieces/run). The experiment was replicated 8 times; a different coral colony was used to generate fragments for each experimental run.

\section{RESULTS}

\section{Injury/temperature interaction}

Prior injury had a significant effect on the ability of Phormidium corallyticum to invade a coral, with $100 \%$ of injured fragments becoming infected compared to none of the uninjured fragments (Wilcoxon signedrank test, $\mathrm{p}<0.01, \mathrm{n}=6$ pairs of fragments) (Table 1 ). In contrast, water temperature did not have a significant effect (Wilcoxon signed-rank test, $\mathrm{p}>0.05, \mathrm{n}=6$ pairs). Injured corals became infected with the disease regardless of temperature condition, whereas uninjured corals never became infected, even in the hightemperature treatment. However, within the injured treatment group, $P$. corallyticum invaded corals at the higher temperature after an average of $1.6 \mathrm{~d}( \pm 0.2 \mathrm{SE})$ compared to an average of $2.3 \mathrm{~d}( \pm 0.2 \mathrm{SE})$ for corals at the low temperature (Wilcoxon signed-rank test, $\mathrm{p}<$ $0.06, \mathrm{n}=6$ pairs). 
Table 1. Montastraea faveolata. Effect (\% coral fragments affected) of Phormidium corallyticum mat placed on coral fragments during temperature treatments. (high temp. $=27.5$ to $29.5^{\circ} \mathrm{C}$, low temp. $=23$ to $25.5^{\circ} \mathrm{C} ; \mathrm{n}=6$ ). Duration of each experiment was 8 to $9 \mathrm{~d}$. Attached: attachment of $P$. corallyticum filaments to living or non-living surface of coral fragment; Invaded: penetration of $P$. corallyticum into coral tissue; Displaced: mat of $P$. corallyticum detached from coral surface; Dead: no visual evidence of $P$. corallyticum mat

\begin{tabular}{|lcccc|}
\hline Treatment & Attached & Invaded & Displaced & Dead \\
\hline $\begin{array}{l}\text { Injured: } \\
\text { high temp. }\end{array}$ & 100 & 100 & 0 & 17 \\
low temp. & 100 & 100 & 0 & 0 \\
Uninjured: & & & & \\
high temp. & 67 & 0 & 50 & 50 \\
low temp. & 67 & 0 & 50 & 50 \\
\hline
\end{tabular}

Of 12 uninjured corals, 6 displaced the Phormidium corallyticum mat from their surface (Table 1). The injured corals never displaced the mat. There was no effect of temperature on this displacement ability, with 3 corals from each group (uninjured high and uninjured low temperature) displacing $P$. corallyticum. Displaced $P$. corallyticum was usually found on the bottom of the beaker, where it frequently grew and spread. In 9 of the 12 uninjured fragments, $P$. corallyticum was able to attach to the non-living, cut side of the coral piece, but was not able to successfully invade the live tissue. By the end of the $9 \mathrm{~d}$ experimental period, there was no evidence of live $P$. corallyticum on 6 of the 12 uninjured fragments. In 1 of the injured fragments, $P$. corallyticum successfully invaded the coral by Day 1 but by Day 7 the size of the mat was diminishing and by Day 9 no live $P$. corallyticum was evident.

\section{Butterflyfish transmission experiments}

The presence of the butterflyfish Chaetodon capistratus increased the rate at which black-band disease spread between coral fragments (Wilcoxon signed-rank test, $\mathrm{p}<0.001, \mathrm{n}=8$ pairs). In 7 of the 8 experimental tanks (with fish), healthy coral became infected with Phormidium corallyticum (Table 2). None of the healthy corals in the tanks without fish (control tanks) contracted black-band disease. The average number of days for $P$. corallyticum to invade the host tissue in tanks with fish was $18.5 \mathrm{~d}$ (range $=5$ to $35 \mathrm{~d}$ ). Transmission of $P$. corallyticum was not dependent on direct contact with the fish, with 6 of the 8 caged coral fragments becoming infected (Wilcoxon signedrank test, $\mathrm{p}=0.65, \mathrm{n}=8$ pairs; Table 2). C. capistratus was observed feeding directly on the black-band mats in the laboratory.

\section{DISCUSSION}

In the laboratory, injury significantly increased the susceptibility of Montastrae faveolata to black-band infection. Phormidium corallyticum was able to invade the tissue of all injured corals but none of the uninjured corals. Injury appeared to impair the defense mechanism of the corals, allowing invasion of the pathogens. Similarly, corals in stressed environments may also have impaired defense mechanisms. Fine \& Loya (2003) studied the competitive outcome between the stony coral Oculina patagonica and bryozoans. Usually O. patagonica is competitively superior to bryozoans, but the competitive outcome was reversed when bleached corals were challenged. Fine \& Loya (2003) found that healthy corals translocated photoassimilates produced by the zooxanthellae to the part of the colony engaged in competition with bryozoans, whereas bleached corals did not. As a consequence, bryozoans were able to overgrow bleached corals. Many studies have suggested that different types of environmental stress may contribute to increases in the incidence of coral disease (Antonius 1989, Santavy \& Peters 1997, Bruckner et al. 1997, Harvell et al. 2001, Bruno et al. 2003). Our results support this, showing that injured $M$. faveolata have a significantly increased susceptibility to black-band disease.

The fact that Phormidium corallyticum did not invade any of the uninjured corals was unexpected, since the black-band mat was placed directly on the corals in a small, enclosed system and presumably all the corals were stressed by the artificial conditions of the experiment, which could have favored $P$. corallyticum invasion of tissue. Apparently, the short-term stress associated with the experiment did not impair the coral's ability to resist invasion by $P$. corallyticum. In fact, half of the uninjured corals were able to completely remove the black-band mat from their surface. Black-band mats initially placed on the coral were

Table 2. Montastraea faveolata. Time required to become infected with black-band disease in presence of a butterflyfish predator. Caged coral were protected from fish predation (fecal transmission), uncaged corals were exposed to fish predation (oral transmission and/or fecal transmission).

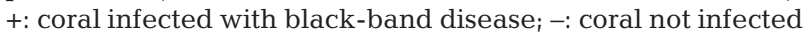

\begin{tabular}{|lccc|}
\hline Coral & Duration of experiment (d) & Caged & Uncaged \\
\hline 1 & 35 & - & - \\
2 & 15 & + & + \\
3 & 20 & + & + \\
4 & 28 & + & + \\
5 & 5 & + & - \\
6 & 12 & + & + \\
7 & 11 & + & - \\
8 & 22 & - & + \\
\hline
\end{tabular}


found at the bottom of the beaker on the following day. On other control corals, the black-band mat was removed from the living surface but was able to attach to the cut sides of the coral. However, the infection was unable to penetrate the tissue. Given more time these mats may have been able to eventually overcome the host's responses and invade the coral.

Microscopic examination of the disease interface of corals revealed that polyps in contact with black-band mats had everted their mesentarial filaments, thereby pushing the mat off of the coral surface. We also observed a high density of nematocysts combined with Phormidium corallyticum filaments in the tissue scraped off the coral. Although merely incidental, these observations do offer some insights into potential mechanisms that Montastraea faveolata may employ in defense against $P$. corallyticum. In one instance, the black-band mat remained on the uninjured coral's surface and even spread across the surface for $6 \mathrm{~d}$. It was initially thought that tissue invasion might have occurred. However, on Day 7, the black-band mat was found on the bottom of the beaker and microscopic examination found no invasive damage apparent on the coral's surface. In contrast, corals with even a slight injury were unable to prevent infection.

Distribution of black-band disease in the field could also be affected by injury to corals, whether by natural or anthropogenic means. The activities of several species of reef fishes cause significant harm to corals. For example, predation by parrotfishes creates large wounds on coral colonies (Bruggemann et al. 1994, Bruckner \& Bruckner 1998) and the activities of certain species of damselfishes can damage corals and even affect the distribution of some coral species (Kaufman 1977, Wellington 1982). Human-inflicted injury, such as anchor or diver damage, could also affect corals. Reefs with corals that suffer any type of mechanical injury would be more susceptible to black-band infection. Incorporating variables such as sources or evidence of coral injury into future field studies should produce a clearer picture of proximate factors affecting disease dynamics.

Temperature did not affect the ability of Phormidium corallyticum to establish black-band disease on a coral. This was unexpected, since field studies have found a higher incidence of black-band disease in the warmer summer months (Antonius 1981, 1985, Rützler et al. 1983, Taylor 1983, Edmunds 1991, Kuta \& Richardson 1996, Bruckner et al. 1997). However, our experiment examined only the initial stages of attachment and invasion of $P$. corallyticum into the coral tissue, not the subsequent rate of progression after invasion. We did find that $P$. corallyticum invaded injured corals in the high-temperature group earlier than injured corals in the low-temperature group. Perhaps increased water temperature does not alter the coral's susceptibility to the attachment and invasion of $P$. corallyticum, but does enhance the rate of progression of the disease across the coral once it has become established.

Other studies have found temperature to be important in initiating the virulence of pathogens. Rosenberg \& Ben-Haim (2002) studied the bacteria Vibrio shiloi, which causes bleaching in the coral Oculina patagonica. They found that bacterial infection only occurred at higher water temperatures in summer, and that several of the bacterial-virulence factors were temperature-regulated. We found no evidence to suggest that the initiation of black-band disease was temperaturedependent. Thus, no correlation between water temperatures and the presence of black-band disease can be drawn at this time.

Under laboratory conditions, the presence of the butterflyfish Chaetodon capistratus increased the rate at which black-band disease spread from diseased to healthy coral fragments. The disease was transmitted to healthy corals in aquaria with the fish but not in aquaria without the fish. This suggests that $C$. capistratus may be involved in the transmission of black-band disease between corals. The mechanism of transfer was not determined, since corals protected from direct contact with fish and corals exposed to fish predation both contracted the disease. Hence, neither direct oral transmission of the pathogen from colony to colony nor indirect fecal transmission could be ruled out. Reef fishes have been found to be vectors for disease transmission in other organisms. For example, they have been implicated in the transmission of the herpes virus, the cause of tumors in green sea turtles. Lu et al. (2000) observed the saddleback wrasse 'cleaning' green sea turtles, including their tumors, and found the snouts of wrasses contaminated with the herpes virus, as well as their liver and gills, suggesting that wrasses acting as vectors might be one mechanism by which the virus is transmitted between turtles.

Other studies have found that foraging activities of butterflyfishes result in transmission of symbiotic algae and parasites. When butterflyfishes feed on corals and other cnidarians, they ingest not only the animal but also the symbiotic zooxanthellae found within cnidarians. Zooxanthellae remain intact and photosynthetically active after passing through the guts of butterflyfishes and are capable of re-infecting host cnidarians (Parker 1984). It was suggested that mobile reef fishes that release viable zooxanthellae in their feces might contribute to the dispersal of zooxanthellae over long distances.

In Hawaii, the coral-feeding butterflyfish Chaetodaon multicinctus is the primary vector for the disease 'Porites trematodiasis' (Aeby 1998a,b, 2002), which is caused by the digenetic trematode Podocotyloides 
stenometra. P. stenometra has a complex life cycle, involving a mollusk as its first intermediate host, Porites sp. coral as its second intermediate host, and coral-feeding fishes as its final host. Coral-feeding fishes become infected with the adult worm when they feed on infected coral. Adult worms live in the guts of fishes, which pass out the trematode's eggs with their feces. C. multicinctus serves as a final host for Podocotyloides stenometra, and since it is the only host capable of large-scale movement, is primarily responsible for spreading this infection across the reef.

In the field, coral-feeding butterflyfishes swim in close proximity to their coral food source, looking for expanded polyps upon which to feed (Tricas 1989b). Hence, anything passed in the fish's feces would have a high probability of landing on the reef before being dispersed by water motion. In addition, butterflyfishes are long-lived, remaining within their territories or home ranges for many years (Reese 1975, 1991, Tricas 1985, 1989a). This long residence time would allow a constant supply of fecal output to the corals in their areas through time. These behaviors (long residence time and proximity to corals) make butterflyfishes effective vectors for transmission of organisms whether these are pathogens, parasites or symbionts.

Water motion has been suggested as one mechanism of dispersal of black-band disease in the field (Bruckner et al. 1997). However, in our experiments no transmission of the disease occurred in aquaria without fish, even though bubblers placed in the aquaria created strong water motion. It could be that either the strength or type of water motion within the aquaria was not appropriate for transmission. However, corals in an enclosed environment a few centimeters $(\sim 10 \mathrm{~cm})$ from a black-band-infected coral never became infected even in the experiment with the longest duration (35 d). This suggests that water motion may not be the only agent required for transmitting black-band disease. In our experimental tanks where disease transmission did occur, it is possible that the fish loosened pieces of the black-band mat when they fed upon the diseased coral fragment, which could have facilitated waterborne transmission. In the field, we observed several species of fishes (juvenile Thalassoma bifaciatum, Chaetodon capistratus, Stegastes fuscus) feeding on the black-band mat of diseased corals. In addition to direct transmission, fishes could also aid disease transmission by loosening the black-band mat, enabling waterborne transmission.

Since our prior experiment had shown that injury increased the susceptibility of Montastraea faveolata to black-band infection, we expected the uncaged corals, exposed to fish predation, to become infected at a faster rate than the caged corals. However, we found no significant difference in the number of infected corals in caged vs. uncaged treatments. The amount of damage that fish inflict when feeding on a coral depends on the fish species. For example, parrotfishes can create large wounds on coral colonies by removing both tissue and skeletal material (Bruckner \& Bruckner 1998), whereas some butterflyfish species have small mouths and pluck out individual polyps with no skeletal damage (Motta 1985). Chaetodon capistratus have small mouths and were observed to feed in a manner consistent with plucking out individual polyps or parts of polyps from the colony. This type of feeding behavior would create minimal injury compared to other feeding habits. Microscopic examination of the corals that had been fed upon by C. capistratus revealed no obvious areas of tissue damage. The minor feeding injury created by this species did not appear to increase the coral's susceptibility to black-band infection.

Alternatively, any increases in disease-susceptibility potentially caused by butterflyfish predation could have been offset by the fish actively feeding on and removing Phormidium corallyticum filaments attempting to invade the coral fragments. Fish feeding on $P$. corallyticum could not only serve to potentially transmit the disease between corals, but could also result in removal of the black-band mat from the infected colony. Opportunistic feeding by fishes on the black-band consortium could benefit infected individual corals, but at the expense of other corals on the reef. Similarly, Aeby (1992) found that butterflyfish offered colonies infected with Porites trematodiasis preferentially fed upon infected polyps. This selective fish predation resulted in the removal of the infection from the infected colony but also resulted in the completion of the parasite's life cycle and thus the ultimate spread of the disease across the reef by infected fish.

The rate at which black-band disease was transmitted between corals in the butterflyfish experiment varied widely from 5 to $28 \mathrm{~d}$. This could be due to a number of factors, such as differences in infectivity between batches of black-band culture, the amount of feeding by individual fish on the black-band consortium, or genotypic differences in disease-susceptibility among corals. When trying to artificially infect corals prior to the experiment, we found that some corals were easily infected whereas other required several attempts before infection was achieved.

In the Florida Keys, Chaetodon capistratus is common on the reefs (see www.reef.org/sanctuaries/ FKNMS) and, in both the laboratory and in the field, was observed feeding on the black-band mat on diseased corals. In the laboratory, the presence of C. capistratus resulted in an increased rate of transfer of black-band disease between corals. We suggest that the butterflyfishes, whether as a vector and/or through 
mechanisms such as displacement of the microbial mat, contribute to the transmission of black-band disease among corals on reefs. Dispersal by butterflyfishes would also offer an alternative explanation for the clumped distribution of black-band-diseased corals reported from some field studies.

The distribution of diseased corals on reefs can provide clues to potential disease processes. However, understanding the patterns of disease prevalence in the field requires knowledge of the proximate mechanisms that affect both disease-susceptibility and transmission. Future disease studies considering factors such as injury or activities by reef fishes would provide a clearer understanding of the dynamics of coral diseases.

Acknowledgements. Research support has been provided by the US Environmental Protection Agency (US EPA) through Cooperative Agreement No. T-826431 with the University of West Florida. Assistance by P. Harris, G. Cripe, K. Smith and W. Burgess is greatly appreciated. Special thanks to F. Blue for help in maintaining aquaria and other systems. B. DeJoseph graciously volunteered numerous hours in data collection. K. Nedimyer, E. Bartells (Mote Marine Laboratory) and J. Hawkridge collected and shipped corals, fishes, and black-band mats from the Keys. Logistical support in the field was provided by staff of the Florida Keys National Marine Sanctuary (FKNMS) and Dry Tortugas National Park (DTNP). The research was conducted under Permit No. 2001-001 (FKNMS) and Permit No. 01S-581 (FWCC). Comments by D. Harvell and several anomynous reviewers greatly improved the manuscript. The research was subjected to review by the National Health and Environmental Effects Research Laboratory and approved for publication. Approval does not signify that the contents reflect the views of the agency, nor does mention of trade names or commercial products constitute endorsement or recommendation for use. This is Contribution No. GED: No. R998 US EPA NHEERL GED. 1 Sabine Island Drive Gulf Breeze, Florida 32561-5299, USA.

\section{LITERATURE CITED}

Aeby GS (1992) The potential effect the ability of a coral intermediate host to regenerate may have had on the evolution of its association with a marine parasite. Proc 7th Int Coral Reef Symp 2:809-815

Aeby GS (1998a) Interactions of the digenetic trematode, Podocotyloides stenometra, with its coral intermediate host and butterflyfish definitive host: ecology and evolutionary implications. PhD dissertation, University of Hawaii, Honolulu

Aeby GS (1998b) A digenean metacercaria from the reef coral, Porites compressa, experimentally identified as Podocotyloides stenometra. J Parasitol 84:1259-1261

Aeby GS (2002) Trade-offs for the butterflyfish, Chaetodon multicinctus, when feeding on coral prey infected with trematode metacercariae. Behav Ecol Sociobiol 52: 158-163

Aeschlimann A (1991) Ticks and disease: susceptible hosts, reservoir hosts, and vectors. In: Toft C, Aeschlimann A, Bolis L (eds) Parasite-host associations: coexistence or conflict? Oxford Science, Oxford, p 149-156

Antonius A (1981) The 'band' diseases in coral reefs. Proc 4th Int Coral Reef Symp 2:7-14
Antonius A (1985) Coral diseases in the Indo-Pacific: a first record. PSZN I: Mar Ecol 6:197-218

Antonius A (1989) Distribution and dynamics of coral diseases in the Eastern Red Sea. Proc 6th Int Coral Reef Symp 2: 293-299

Bigger C (1988) The role of nematocysts in anthozoan aggression. In: Hessinger DA, Lenhoff HM (eds) The biology of nematocysts. Academic Press, New York, p 295-308

Bronikowski EJ (1982) The collection, transportation, and maintenance of living corals. In: Annual Proceedings of American Zoological Parks and Auqarisms (AAZPA). Wheeling, WV, p 65-70

Bruckner A (2002) Priorities for effective management of coral diseases. NOAA Tech Memo NMFSOPR-22

Bruckner A, Bruckner R (1998) Destruction of coral by Sparisoma viride. Coral Reefs 17:350

Bruckner A, Bruckner R, Williams E Jr (1997) Spread of a black-band disease epizootic through the coral reef system in St. Ann's Bay, Jamaica. Bull Mar Sci 61:918-928

Bruggemann J, van Oppen M, Breeman A (1994) Foraging by the stoplight parrotfish, Sparisoma viride. I. Intake and assimilation of food, protein and energy. Mar Ecol Prog Ser 106:41-55

Bruno JF, Petes LE, Harvell D, Hettinger A (2003) Nutrient enrichment can increase the severity of coral diseases. Ecol Lett 6:1056-1068

Carlton R, Richardson L (1995) Oxygen and sulfide dynamics in a horizontally migrating cyanobacterial mat: black band disease of corals. FEMS Microbiol Ecol 18:155-163

Cox EF (1986) The effects of a selective corallivore on growth rates and competition for space between two species of Hawaiian corals. J Exp Mar Biol Ecol 101:161-174

Edmunds PJ (1991) Extent and effect of black-band disease on a Caribbean reef. Coral Reefs 10:161-165

Ewald P (1987) Transmission modes and evolution of the parasitism-mutualism continuum. Ann NY Acad Sci 503: 295-306

Ewald P (1994) Evolution of infectious disease. Oxford University Press, Oxford

Fine M, Loya Y (2003) Alternate coral-bryozoan competitive superiority during coral bleaching. Mar Biol 142:989-996

Gochfeld D (2004) Predation-induced morphological and behavioral defenses in a hard coral: implications for foraging behavior of coral-feeding butterfly fishes. Mar Ecol Prog Ser 267:145-158

Gunthorpe L, Cameron A (1990) Widespread but variable toxicity in scleractinian corals. Toxicon 28:1199-1219

Harvell D, Kim K, Quirolo C, Weir J, Smith G (2001) Coral bleaching and disease: contributors to 1998 mass mortality in Briareum asbestinum (Octocorallia, Gorgonacea). Hydrobiologia 460:97-104

Hidaka M, Miyazaki I (1984) Nematocyst discharge and surface structure of the ordinary and sweeper tentacles of a scleractinian coral. Galaxea 3:119-130

Hidaka M, Miyazaki I, Yamazato K (1987) Nematocysts characteristic of the sweeper tentacle of the coral Galaxea fascicularis (Linnaeus). Galaxea 6:195-207

Hourigan T (1987) The behavioral ecology of three species of butterflyfishes (family: Chaetodontidae). PhD dissertation, University of Hawaii, Honolulu

Jones G, Ferrell D, Sale P (1991) Fish predation and its impact on the invertebrates of coral reefs and adjacent sediments. In: Sale P (ed) The ecology of fishes on coral reefs. Academic Press, New York, p 156-179

Kaufman L (1977) The threespot damselfish: effects on benthic biota of Caribbean coral reefs. Proc 3rd Int Coral Reef Symp 1:560-564 
Koh E (1997) Do scleractinian corals engage in warfare against microbes? J Chem Ecol 23:379-398

Kosaki R (1988) Predation by Chaetodon trifasciatus and growth and distribution of Pocillopora damicornis at Coconut Island, Oahu, Hawaii. Pac Sci 43:195

Kosaki R (1999) Behavioral mechanisms of coexistence among coral-feeding butterflyfishes. PhD dissertation, University of Hawaii, Honolulu

Kuta K, Richardson L (1996) Abundance and distribution of black-band disease on coral reefs in the northern Florida Keys. Coral Reefs 15:219-223

Kuta K, Richardson L (2002) Ecological aspects of black band disease of corals: relationships between disease incidence and environmental factors. Coral Reefs 21:393-398

Lu Y, Lu Q, Zamzow J, Wang Y, Losey G, Balazs G, Nerurkar V, Yanagihara R (2000) Detection of green turtle herpes viral sequence in saddleback wrasse Thalassoma duperrey: a possible mode of transmission of green turtle fibropapilloma. J Aquat Anim Health 12:58-63

Mariscal RN (1974) Nematocysts. In: Muscatine L, Lenhoff HM (eds) Coelenterate biology: reviews and new perspectives. Academic Press, New York, p 129-178

Mascarelli P, Bunkley-Williams L (1999) An experimental field evaluation of healing in damaged, unbleached and artificially bleached star coral, Montastraea annularis. Bull Mar Sci 65:577-586

McCallum HI, Kuris A, Harvell D, Lafferty KD, Smith GW, Porter J (2004) Does terrestrial epidemiology apply to marine ecosystems? Trends Ecol Evol 19:585-591

Miller M, Hay M (1998) Effects of fish predation and seaweed competition on the survival and growth of corals. Oecologia 113:231-238

Motta P (1985) Functional morphology of the head of Hawaiian and Mid-Pacific butterflyfishes (Perciformes, Chaetodontidae). Environ Biol Fish 13:253-276

Mullen K, Peters E, Harvell DC (2004) Coral resistance to disease. In: Rosenberg E, Loya Y (eds) Coral health and disease. Springer-Verlag, Berlin, p 377-399

Neudecker S (1979) Effects of grazing and browsing fishes on the zonation of corals in Guam. Ecology 60:666-672

Parker GM (1984) Dispersal of zooxanthellae on coral reefs by predators on cnidarians Biol Bull (Woods Hole) 167:

Editorial responsibility: Charles Birkeland (Contributing Editor), Honolulu, Hawaii, USA
$159-167$

Reese E (1975) Duration of residence by coral reef fishes on 'home' reefs. Copeia 1:145-149

Reese E (1991) How behavior influences community structure of butterflyfishes (family: Chaetodontidae) on Pacific coral reefs. Ecol Int Bull 19:29-41

Richardson L, Kuta K, Schnell S, Carlton R (1997) Ecology of the black band disease microbial consortium. Proc 8th Int Coral Reef Symp 1:597-600

Rosenberg E, Ben-Haim Y (2002) Microbial diseases of corals and global warming. Environ Microbiol 4:318-326

Rützler K, Santavy D (1983) The black band disease of Atlantic reef corals. I. Description of the cyanophyte pathogen. PSZN I: Mar Ecol 4:301-319

Rützler K, Santavy D, Antonius A (1983) The black-band disease of Atlantic reef corals. III: Distribution, ecology and development. PSZN I: Mar Ecol 4:329-358

Santavy DL, Peters EC (1997) Microbial pests: coral disease in the Western Atlantic. Proc 8th Int Coral Reef Symp 1: $607-612$

Sussman M, Loya Y, Fine M, Rosenberg E (2003) The marine fireworm Hermodice carunculata is a winter reservoir and spring-summer vector for the coral-bleaching pathogen Vibrio shiloi. Environ Microbiol 5:250-255

Sutherland K, Porter J, Torres C (2004) Disease and immunity in Caribbean and Indo-Pacific zooxanthellate corals. Mar Ecol Prog Ser 266:273-302

Taylor DL (1983) The black-band disease of Atlantic reef corals. II. Isolation cultivation and growth of Phormidium corallyticum. PSZN I: Mar Ecol 4:321-328

Tricas T (1985) The economics of foraging in coral-feeding butterflyfishes of Hawaii. Proc 5th Int Coral Reef Conqr 5: 409-414

Tricas T (1989a) Determinants of feeding territory size in the corallivorous butterflyfish Chaetodon multicinctus. Anim Behav 37:830-841

Tricas T (1989b) Prey selection by coral-feeding butterflyfishes: strategies to maximize the profit. Environ Biol Fish 25:171-185

Wellington G (1982) Depth zonation of corals in the Gulf of Panama: control and facilitation by resident reef fish. Ecol Monogr 52:223-241

Submitted: April 2, 2004; Accepted: November 16, 2005

Proofs received from author(s): July 5, 2006 